DOI https://doi.org/10.30525/978-9934-26-172-5-8

\title{
РОЗРОБКА ФУНКЦІОНАЛЬНИХ ЕРГОНОМІЧНИХ ВИМОГ ДО АДАПТИВНОЇ ІНТЕЛЕКТУАЛЬНОЇ СИСТЕМИ ПІДТРИМКИ ПРИЙНЯТТЯ РІШЕНЬ 3 РОЗВИТКУ НАВИЧОК САМОСПРЯМОВАНОГО НАВЧАННЯ ДЛЯ АВІАДИСПЕТЧЕРІВ
}

\author{
Пальоний А. С. \\ кандидат технічних наук, \\ в.о. завідувача кафедри обслуговування повітряного руху \\ Льотна академія \\ Національного авіачійного університету \\ м. Кропивницький, Украӥна
}

Технологічність сучасної професійної освіти обумовлює збільшення ролі засобів навчання, розроблених на основі сучасних інформаційних технологій, та зростання важливості індивідуального підходу до підготовки, отже все більшого поширення набувають автоматизовані системи навчання. Новітні тренди в вищий професійній освіті пов'язані, зокрема, з метакогнітивних навчанням здобувачів вищої освіти у закладах вищої освіти. Адже підвищенні сучасні вимоги до висококваліфікованого фахівця, зокрема, диспетчера управління повітряним рухом (УПР), обумовлюють необхідність у створенні умов для цілеспрямованого опанування ним тих знань, умінь та якостей, які сприятиме його успішному професійному розвитку, безперервному підвищенню кваліфікації протягом всього професійного життя за рахунок розвиненої самоорганізації, особистого i фахового самовдосконалення. Згідно концепції ІКАО «Контроль факторів загрози та помилок (КУО) при управлінні повітряним рухом» загрози і помилки $\epsilon$ частиною діяльності авіації, 3 якими диспетчера УПР повинні справлятися, оскільки неконтрольовані загрози та помилки можуть спровокувати появу небажаних станів [1, с. 2]. Одним 3 завдань самоспрямованого навчання $(\mathrm{CCH}) \in$ навчити авіадиспетчера самому ідентифікувати, аналізувати і своєчасно виправляти власні помилки, більш ефективно керувати власним когнітивним навантаженням, використовуючи при цьому розвинені навики рефлексії.

У світлі потреби забезпечення інформаційної та консультативної підтримки майбутніх авіадиспетчерів, з метою ефективного розвитку ними навичок $\mathrm{CCH}$ як в режимі самостійної передтренажерної самопідготовки, так і в аудиторному форматі, актуальним завданням постає розробка адаптивної інтелектуальної системи підтримки прийняття 
рішень (АІ СППР), що використовує методи штучного інтелекту та грунтується на використанні інтелектуальних агентів. Очікується, що така АI СППР буде виступати функціональним модулем, інтегрованим до автоматизованої системи передтренажерної підготовки диспетчерів УПР. Але спочатку потрібно визначити функціональні ергономічні вимоги до самої АІ СППР для вдоволення навчальних потреб учнякористувача такої системи.

Такі відомі дослідники як M. S. Knowles, L. Turos, В. Олійник, С.М. Прийма, С.I. Змеєв, О.А. Орлова, Л. Вовк, Л. Сігаєва та ін., займались питаннями андрагогіки, що мають важливе значення для розробки теми нашого дослідження. Цими вченими сформульовано основні положення i принципи андрагогіки, завдяки яким стає можливим ефективне функціонування системи неперервної освіти дорослих [2, с. 111-112]. Одне з перших найбільш чітких визначень ССН походить від Ноулза, який описав його як «процес, в якому люди беруть на себе ініціативу, за допомогою чи без допомоги інших, у діагностуванні своїх потреб у навчанні, самостійному формулюванні та корегуванні навчальних цілей, виявленні людських i матеріальних ресурсів для навчання, вибір та впровадження відповідних стратегій навчання та оцінка результатів навчання» [3, с. 41]. Brockett R. G. та Hiemstra R. запропонували модель «орієнтації на особисту відповідальність», у якій два взаємопов'язані виміри, а саме зовнішні характеристики навчального процесу i внутрішні характеристики того, хто навчається, об'єднані в одне парасолькове поняття «самонаправлення у навчанні» [4]. Проблеми моделювання та запровадження CCH досліджувались Winne P. H., Hadwin A. F., Zimmerman B. J., Schunk D. H., Pintrich P. R., Robertson J., Siadaty M., Loyens S. M. M., Magda J., Jossberger H., Brand-Gruwel S., Boshuizen H., Wiel M., Dale H. та іншими. Що стосується саморегульованого навчання, то щодо нього існують різноманітні погляди, а дослідники 3 різних осередків намагаються моделювати, як когнітивні, метапізнавальні, мотиваційні та контекстуальні фактори впливають на процес навчання.

В контексті розробки та реалізації АІ СППР з розвитку навичок $\mathrm{CCH}$ (AI СППР РНСН) для учня-користувача, доцільно ввести поняття «адаптивний функціональний комфорт» (АФК). Під адаптивним функціональним комфортом ми визначаємо «функціональний стан користувача, зайнятого навчальним процесом, при якому навчальне середовище та умови його забезпечення повністю відповідають функціональним можливостям людини, адаптуючись до поточних навчальних потреб та очікувань учня, його стильових особливостей, когнітивного рівня та метакогнітивного досвіду. При цьому спостерігається позитивне ставлення учня до навчання, що обумовлює 
адекватну мобілізацію психофізіологічних процесів, віддаляє появу стомлюваності, сприяє зростанню мотивації та збереження іiі на високому рівні протягом всього часу підготовки».

Слід зауважити, що реалізація самоспрямованого навчання в форматі передтренажерної підготовки авіадиспетчерів не $\epsilon$ самоціллю, а виступає засобом формування спеціальних компетентностей з ССН для їх «перенесення» до адаптивної тренажерної підготовки авіадиспетчерів 3 метою використання в режимі саморегуляції. Адже будь-яка система тренажерної підготовки висуває досить жорсткі вимоги щодо іiі організації та проведення 3 позиції регульованості навчання. Тоді завдання оптимізації для адаптивної передтренажерної підготовки авіадиспетчерів можна сформулювати так: «Для заданих технічних засобів навчання, комплексу стратегій розвитку спеціалізованих стратегій формування навичок $\mathrm{CCH}$, рівня й формату інформаційної та консультативної підтримки і ресурсних можливостей для користувача (довідкових, показових, методичних, консультативних), часових, стратегічних і тактичних обмежень керованості навчанням з боку учня, забезпечити максимум ймовірності бажаного результату навчання (як фаховим вмінням та навикам, так і навичкам $\mathrm{CCH}$ ) та максимум АФК».

Визначимо найбільш актуальні для користувача складові АФК:

- АФК1 - метакогнітивний АФК;

- АФК2 - стильовий АФК;

- АФКЗ - керувальний АФК;

- АФК4 - складністний АФК;

- АФК5 - часовий АФК.

Окрім безпосереднього використання учнем навичок $\mathrm{CCH}$ під час формування фахових компетентностей, йому надається можливість рефлексувати по відношенню до рівня й динаміки розвитку самої спеціалізованої компетентності з ССН. Для вирішення цього завдання до АІ СППР повинно бути інтегровано технологію самоконтролю та пояснювальну компоненту (АФК1). На підставі отриманих даних i рекомендацій від АI СППР РНСН, учень повинен мати змогу керувати формуванням навичок ССН шляхом визначення наявних недоліків та обрання ефективних метакогнітивних стратегій їх розвитку з переліку рекомендованих системою, з урахуванням індивідуальних стилів навчання та стилів метакогнітивної організації навчання. При цьому користувач повинен отримувати відповідну інформацію та рекомендації від системи $з$ адаптованим до учня стилем подання інформації, рівнем наочності, деталізованості та інтерактивності (АФК2). Механізм реалізації метакогнітивних стратегій передбачає впорядкування процесів керування власною пізнавальною діяльністю та досягання певних когнітивних цілей. При цьому учень має можливість 
вибору (АФК3): або комплексно задіяти всі навички $\mathrm{CCH}$, або зробити акцент на відпрацюванні окремих складових спеціалізованої ССН-компетентності, тобто відпрацювати у даній тренувальній сесії за вибірковими іï компонентами. Реалізація складністного АФК (АФК4) стосується інтелектуального аналізу даних поточної моделі учня: початкового рівня готовності до ССН, стильових та когнітивних переваг і обмежень; історичних даних формування фахових компетентностей та рівня й характеру розвитку спеціальної ССН-компетентності у їх взаємозв'язку; динаміки зміни рівня вмотивованості тощо. Часовий АФК (АФК5) передбачає безперервний контроль резерву часу з боку системи i самим учнем, 3 врахуванням індивідуального темпу формування фахових і ССН-субкомпетентностей, для реалізації окремих частин навчання, та прийняття рішення щодо індивідуального оптимального шляху навчання на кожній ділянці, що залишилось пройти до завершення навчання.

Таким чином, традиційні системи підтримки прийняття рішень мають цілу низку недоліків: інформаційне перевантаження, сильна залежність учня від АІ СППР, девальвація суб'єктивності при прийнятті рішень, використання соціально ізолюючих методів навчання тощо. Такі недоліки $\epsilon$ критичними в сфері їх практичного застосування при формуванні в користувачів навичок $\mathrm{CCH}$ та повинні бути повністю ліквідовані на етапі розробки АІ СППР РНСН, в іншому випадку система взагалі не може використовуватися за призначенням. Запропоновані ергономічні складові «адаптивного функціонального комфорту» користувача при роботі з системою повинні бути покладені в основу розробки вимог щодо функціонування відповідної СППР.

\section{Література:}

1. Контроль факторов угрозы и ошибок (КУО) при управлении воздушным движением: Cir. ICAO 314 - AN / 178. Монреаль, Канада, 2008. 35 c.

2. Змеев С. И. Андрагогика: основы теории, истории и технологии обучения взрослых. М.: ПЕР СЭ, 2007. 272 с.

3. Knowles M. S. The Modern Practice of Adult Education. From Pedagogi to Andragogiy. Chicago.1980. P. 13-60.

4. Brockett R. G., Hiemstra R. A conceptual frameword for understanind self-direction in adult learning. Self-Direction in Adult Learning: Perspectives on Theory, Research, and Practice, London and New York: Routledge. 1991. URL: https://infed.org/mobi/a-conceptual-framework-for-understanding-self-direction-in-adult-learning/ (Last accessed: 13.11.2021) 